Oana Celia Gheorghiu,

Michaela Praisler

"Dunarea de Jos"

University of Galati, Romania
2020, Vol. 17 (1), 87-96(164)

revije.ff.uni-lj.si/elope

https://doi.org/10.4312/elope.17.1.87-96

UDC: 141.72:821.111(71).09-31Atwood M.

\title{
Rewriting Politics, or the Emerging Fourth Wave of Feminism in Margaret Atwood's The Testaments
}

\begin{abstract}
Margaret Atwood's The Handmaid's Tale (1985) has recently returned to the spotlight with the success of its TV adaptation and with her decision to deliver a sequel. Speculative fiction invites speculative criticism; in this spirit, this paper investigates The Testaments (2019), tracing the rewriting of politics embedded in the narrative. Whilst the inspiration for The Handmaid's Tale came from the rise of Christian fundamentalism, it is obvious from Atwood's more recent statements that she considers the Trump era "a rollback of women's rights" (2018). The slogan of second-wave feminists, 'the personal is political,' is now as topical as it was in the 1960s, and The Testaments may well become a literary manifesto of a new (fourth) wave as part of the storm surge of feminism. Therefore, before turning to Atwood, an outline of the chronological clashes of feminism(s) and a discussion on women and language is presented. This is followed by an examination of the three main characters and representatives of ideas.
\end{abstract}

Keywords: feminism; women's writing; politics; The Handmaid's Tale; sequel; Margaret Atwood

\section{Preoblikovanje politike oz. nastajajoč četrti val feminizma v delu Testamenti avtorice Margaret Atwood}

\section{POVZETEK}

Roman Deklina zgodba (1985) avtorice Margaret Atwood se je zaradi uspeha televizijske priredbe in obljube po nadaljevanju romana pred kratkim znova znašel v središču pozornosti. Fantazijska proza prinaša tudi fantazijsko kritiko; v luči tega v prispevku analiziramo delo Testamenti (2019), ki sledi preoblikovanju politike, vpete v pripoved. Medtem ko navdih za roman Deklina zgodba izhaja iz krščanskega fundamentalizma, je iz dandanašnjih izjav Margaret Atwood jasno, da Trumpovo obdobje po njenem mnenju predstavlja »zmanjševanje pravic žensk« (2018). Slogan feministov drugega vala, »osebno je politično«, je zdaj ravno tako aktualen kot v 60. letih 20. stoletja, delo Testamenti pa bo morda postalo literarni manifest novega (četrtega) vala kot del nevihtnega pojava feminizma. Zaradi tega $\mathrm{v}$ prispevku najprej predstavljamo kronološki pregled feminizma ter razpravo o ženskah in jeziku. Sledi analiza treh glavnih junakinj in predstavnic idej.

Ključne besede: feminizem; ženska proza; politika; Deklina zgodba; nadaljevanje; Margaret Atwood 


\section{Feminism Coming Fo(u)rth}

Women's disentanglement from patriarchy comes in surges, in 'streams of consciousness' tend to overflow when the personal departs too much from the political, or when femininity feels threatened by its 'significant other.' History, indebted to a certain extent to a masculine appetency for order, linearity and hierarchy, lists the feminist waves in a diachrony of aims and purposes, which are briefly mentioned here. The first wave (late 19th to early 20th centuries) focused on acquiring equal rights, including the right to vote, on the grounds that women have the same minds and interests as men. The second (the late 1960s and beyond) followed the post-war decades of women's being re-assigned the traditional domestic roles of (house) wives and mothers and emerged against a background of intellectual activists who protested politically, in writing as well as in the streets. The third wave (towards the 1990s and well into the noughties) acknowledged that equality had been accomplished and that new raisons d'être had therefore to be found. The predilection of academic gender studies for the posts of the time (postmodernism, poststructuralism and postcolonialism) highlighted difference and différance and, predictably, introduced postfeminism as a mark of the third wave.

In theorizing the third wave, scholars claim that it is not associated with the idea of a time after feminism, or the realization of feminist aims, but that it implies that feminism has undergone a radical transformation in relation to the values that postmodernism questions (Genz and Brabon 2009) and, in line with the postmodern, aims to disrupt grand narratives or interrupt dominant, imperialistic views of gender and inequality (Rivers 2017, 17). This disputes Faludi's seminal 1992 Backlash, where she claimed that postfeminism (as both a term and a trend) was actively employed in discrediting feminism as a relevant political movement, in outdating its usefulness. Judging by the preface she wrote for the 2006 edition of her book, Faludi remained sceptical of postfeminism, which, to her mind, turned self-determination into a "commodified self-improvement of physical appearance, self-esteem and the fool's errand of reclaiming one's youth" and public agency into publicity $(2006, \mathrm{xv})$, with the only result of having "gilded our shackles instead of breaking them" (xvi). This calls for an intervention of the past, for a second-wave revivalist movement that would regain that which its daughters lost. Much of the third-wave theory is based on writings of daughters of second-wave feminists who contest their mothers' views and activism(s), their concern with the white, heterosexual, middleclass woman. Rebecca Walker, the coiner of the "third wave" term, is Alice Walker's daughter and Gloria Steinem's goddaughter; Katie Roiphe is Anne Roiphe's daughter, to give just two examples. ${ }^{2}$ Another "bone of contention" (Atwood 2010,313) is the older generation's take on motherhood, openly against the feminine mystique that Betty Friedan described in the 1960s as "a rush for the security of togetherness" in the "cozy walls of home" which had become "a pattern by which all women must [...] live or deny their femininity" $(2001,37)$.

It is now the granddaughters' time, and they look back in anger at the kind of empowerment that their mothers advocated at the expense of their actual freedom and in admiration at

This refers neither to the streams imagined by psychologist William James in The Principles of Psychology (1890), nor to the Modernist narrative mode, but to a reprocessed and appropriated understanding of a collective deluge of ideas shared by individuals towards the emergence of philosophical, political and social movements.

2 See Rivers 2017, 16-19 for an extensive discussion on this matter. 
their grandmothers' struggle, which was left behind for having outlived its purposefulness. All this has brought to the fore women's objectification, sexual harassment and abuse for a generation that sees things differently from their mothers and grandmothers: "Generational specificity implies that waves emerge when a younger group of women come to the politics, looking to shape a social movement that is more accommodating of, and tailored to their identity" (Chamberlain 2017, 8). The fourth wave, which now seems to be settling in, is at the same time different from and similar to both the second and the third ones. Baumgardner claims that it is "an almost-return to some of the thinking of the second wave, with a greater emphasis on identity politics that were dismantled within the third wave" $(2011,72)$. Others juxtapose the feminist waves (with their theories conceptualised as stories):

Despite each story's proclamations of difference from the other accounts, there are striking narrative similarities that link these stories and that facilitate discursive movement between them without apparent contradiction. [...] All three stories divide the recent past into clear decades to provide a narrative of progress or loss, proliferation or homogenization. Stories of return are equally invested in these distinctions to argue for what it is that we need to return to in order to rescue Western feminist theory. (Hemmings 2011, 5)

These two approaches to contemporary feminism cannot be debunked as erroneous, nor embraced as definitively correct. Briefly, this is what has happened with feminisms in the real world, the world where things that many contemporary writers put in their books 'have already happened,' the world which gets to be translated into fiction by authors who weave texts made up of "multiple writings, issuing from several cultures and entering into dialogue with each other" (Barthes 1967), for the benefit of readers who can take whatever they want from the text. The writer is, however, not entirely dead, but silenced, muffled in the polyphony of voices belonging to those who access the world(s) of the text. At times, novelists rebel and try to take their worlds back. This usually happens when they explain their intentions behind the text, by endowing it with paratextual assessments, or when they write sequels or prequels, or find other forms of linking their current world outside the text to their past ones, which once gave birth to alternative textualised worlds that still raise questions.

A case in point is The Testaments, Margaret Atwood's recent follow-up to her famous The Handmaid's Tale, designed to match the realities of the late 2010s. Drawing a parallel between the history of feminism and the women's fate in the original novel and its sequel, one could place the many analepses in the former text into postfeminism / the third wave, although the terms were not yet in use at the time of the novel's publication. Many readers of The Handmaid's Tale have noted the implied critique of second-wave feminism - mainly in the relation between Offred and her militantly feminist mother, but also in its emphasis on the horrible things that women can do to each other once the male dictatorship forces them to act in their own interests, at the expense of their peers' wellbeing. If third-wavers manifest a "kind of twisted Electra complex within which daughters are committed to killing off mothers" (Halberstam 2012, 2), by contrast, in The Handmaid's Tale, the protagonist's generation (women in their thirties or just under) no longer needs the activism of their mothers. They have careers, rights, sexual freedom, and freedom of speech; in a nutshell, they already have everything for which their predecessors fought, thus rendering the fight superfluous, until they no longer have anything, and it is too late to fight back. 
Each ebb and flow of feminism seems to emerge from and simultaneously contest its immediate forerunner. This is true for all cultural movements, from the Enlightenment to postmodernism. Although the debate is in its early stages and an outline of the politics of the fourth wave remains to be determined, we favour Baumgardner's opinion quoted above, namely, that the fourth wave is a technologically improved second wave and a contestation of 1990s-2000s postfeminism rather than its continuation. And if we were to identify representations of the feminist waves in The Handmaid's Tale / The Testaments (disregarding, in a Barthesian manner, whether Atwood thought of that - after all, we, readers are as free to speculate as she is), we could consider the (Gileadean) women's liberation movement in The Testaments as having a counterpart in the (real) present-day / near future marked by the emergence of this fourth wave that is yet to have a literature of its own nor, what is more, a theory of its own. Thus, in the attempt to contextualise The Testaments within a newly-born feminist insurgence against the patriarchal resurgence of the Commanders Waterford and Judd of our time, we resort to the sexualltextual theories of the second wave, more specifically to women's empowerment through writing, as advocated by Hélène Cixous, among others.

\section{Voler et différance}

Woman is - customarily - on the side of passivity. As French feminist philosopher Hélène Cixous famously observed in her seminal essay "Sorties," especially in philosophy and literature: "Philosophy is constructed on the base of woman's abasement. Subordination of the feminine to the masculine order, which gives the condition for being the machinery's functioning." Her antidote is the notion of écriture féminine, which involves the concept of voler (as both stealing and flying - stealing language and its structure only to make it shift, fly away from its fixed paradigms). In an introduction to "Sorties," Katarzyna Marciniak points out that Cixous herself re-conceptualises the discourse of philosophy by stealing it and flying from it through her mixing of poetry and theory: "By writing a theoretical piece in a passionate, highly visual and poetic way, she risks the accusation of being emotional, and not rational" - which brings us back to patriarchal arguments regarding women's writing as being incapable of rendering anything other than emotions (usually in the form of a personal diary). However, this is exactly what she intends - "to demonstrate how writing lingers in the space of différance and how being discursively passionate and sensual does not have to signify irrationality" (1986).

Perhaps starting from Cixous's oppositions is bold, especially when discussing Atwood, an author who has constantly rebuffed her association with feminism (in fiction) - which, as is well-known, has happened often throughout her career. It has already been done, albeit in reference to Offred's testimony, which we (or the participants in the "Twelfth Symposium on Gileadean Studies") access in the form of written text:

$[\mathrm{O}]$ nly at the end do we discover that what we have been reading was actually a spoken narrative which has been transcribed from old cassette tapes and reconstructed for publication long after the narrator is dead. This complicated transmission process from private speech act to written text illustrates the historical problem of women's silencing which Cixous has highlighted, and also the potentially disruptive effects of women's writing. (Howells 2003, 165) 
Our intention is to prove that Atwood, perhaps unconsciously, attempts, with her latest opus, to destabilize the contemporary hierarchies through these disruptive effects of women's writing, and even to actively participate in the rebirth of second-wave feminism, rebranded as the fourth wave. The famous feminine gibberish placed in Molly Bloom's mouth as the final pronouncement of Joyce's Ulysses, "and yes I said yes I will Yes" (2010: 682) can be reworked as female agency and self-empowerment in an era when President Trump makes a derogatory remark about women ${ }^{3}$ every other day, when the \#MeToo movement brings condemnation to dozens of powerful men in politics, business, entertainment and the news media, some of whom have been found guilty of sexual abuse and harassment. If The Handmaid's Tale was, in its day, a cautionary tale - it might happen and it has somehow happened elsewhere - The Testaments could be Atwood's contribution, overtly militant, to a women's 'march against patriarchal abuse' comparable to that which took place on January 21, 2017, one day after Trump's inauguration. As a parenthesis, as many as 4.6 million people attended it, in various places in the United States, making the Women's March perhaps the largest single-day demonstration in the country's history, according to Time (2017). The momentum carried forward to cover textual ground, significantly raising, once again, the interest in feminist writing. According to Nielsen Bookscan, the 2019 sequel The Testaments sold more than 100,000 copies in one week. Vintage claims that the title was their hardback of the year and, interestingly, that it also galvanised interest in The Handmaid's Tale, which came a close second in sales, 34 years after its publication. Numbers count, and so does the Booker Prize, awarded some three weeks after publication, even when breaking hypothetical political hierarchies is at stake and made explicit. In connection with the prize, Atwood noted that reader had been asking her about The Handmaid's Tale for years, arguing that "as time moved on, instead of moving further away from Gilead we moved towards it, particularly in the US" (quoted in Enright 2019).

Proof may lie in The Handmaid's Tale (1985), which has enjoyed wide critical attention since its publication, having been inscribed in the category of the 20th-century's most accomplished dystopian works, alongside Huxley's Brave New World, Bradbury's Fahrenheit 451, and Orwell's 1984. The launch of a sequel, The Testaments, as well as the successful adaptation of The Handmaid's Tale into a TV series, have brought the novel back into the limelight. The former is supposed to resolve some of the questions left unanswered by not one but two open-endings, and raises an increased concern with what is currently going on in the United States in terms of state policies and the political stance assumed by the author in the media.

Margaret Atwood has been prompted to deliver a sequel to expand on Offred's progress beyond the days recorded in the transcript of her spoken diary. It is still arguable whether her undertaking is purely political, a result of her dissatisfaction with the scriptwriters' taking over the narrative from its confusing open-ending to the second and third series of the show, or whether it is determined by reasons of cultural commodification. Most probably, it is all the above. As Anne Enright, reviewing the book for The Guardian, remarks, "in writing The Testaments, she also reclaims its world from all the people who think they own it now: the writers of fan-fiction and the television producers (she told them they could not kill Lydia,

See "61 things Donald Trump has said about women" The Week, 2018. https://theweek.com/articles/655770/61things-donald-trump-said-about-women. 
apparently). A story that feels universal is, actually, hers: she gets to decide." Atwood's demand that Lydia should not be killed or, in TV series jargon, written off, has been explained by the plot of The Testaments, in which the character plays a major role. In other words, in which she is a protagonist, narrator, propelling force, manipulator of power, etc.

In The Handmaid's Tale, though oblique, the politics advanced by Atwood was clear, as was her criticism: history is practically his-story, overlooking hers. Historical Notes on The Handmaid's Tale brings literary art to cover political ground via Pieixoto's authenticating endeavour, which focuses on 'the commander' (Judd, Waterford - male characters based on real, documented people), not on Offred - female undocumented narrator, therefore unreal. (Praisler and Gheorghiu 2019, 182)

In The Testaments, on the other hand, although as clearly as in The Handmaid's Tale, the politics advanced by Atwood takes a road less travelled and more obviously feminist: against the almost unbearably graphic background of women's abasement in the early days of Gilead, his-story subversively becomes her-story. In Cixous's terms, authority and control are left in the hands of women who have been "subordinated to the masculine order, towards the functioning of [Gilead's] machinery" (1986). Some of the women of Gilead acquire that "bisexuality" (i.e., emasculation) which is "the location within oneself of the presence of both sexes" (Cixous). They are forced into it by unimaginable means: starvation, solitary confinement, lack of hygiene, the obligation to witness and participate in public executions on either end of the barrel of a gun, etc. The extended descriptions in the analepses that make up large portions of Aunt Lydia's diaries are, in the Naturalist manner, abominable and nauseating, pointing to dehumanisation (or defeminisation):

I frequently pictured a beautiful, clean white toilet. Oh, and a sink to go with it, with an ample flow of pure clear water. Naturally we began to stink. In addition to the ordeal by toilet, wed been sleeping in our business attire, with no change of underwear. Some of us were past menopause, but others were not, so the smell of clotting blood was added to the sweat and tears and shit and puke. To breathe was to be nauseated. They were reducing us to animals - to penned-up animals - to our animal nature. (Atwood 2019, 143)

The choice given is simple: 'eat or be eaten'; side with the male power to become powerful yourself. Cast away your femininity and punish others for keeping theirs. Lydia, formerly a respected judge, chooses life over femininity and accepts to join the masculine ranks of the tormentors. But this bisexualization, or should we say bi-gender-ization, ricochets, as the acquired masculine traits completely, though ironically, take over the feminine ones.

If, in one sense, Derrida's différance points to difference, and the chains of differential marks engender binary oppositions, the overlapping of femininity and masculinity with which Atwood endows the Aunts comes at the end of The Testaments, secretly and subversively, to invert the opposition completely. Given male power, women take over. Elles volent, taking the power from a masculine order that has become too confident in its accomplishment of women's submission and has consequently started to be negligent and/or to (re)turn to manas-brute's habits of sexual abuser (i.e., beyond the obvious abuse against the handmaids and 
wives in The Handmaid's Tale). However, in Aunt Lydia's case, this empowered femininity - although the term is questionable - also leaves room for insecurity and disquiet with what it has turned into: "I've become swollen with power, true, but also nebulous, shape-shifting. I am everywhere and nowhere: even in the minds of the Commanders I cast an unsettling shadow. How can I regain myself? How to shrink back to my normal size, the size of the ordinary woman?" (Atwood 2019, 33). In this context, normalcy and ordinariness seem to be tongue-in-cheek qualifiers for womanhood, in the sense of women's lower, secondary position in relation to men, one that is apparently acknowledged and desired by this character burdened with power. If one were to look for literary analogies to women that became too empowered, one could cite the famous plea of Lady Macbeth: "unsex me here, / And fill me from the crown to the toe top-full / Of direst cruelty" (Macbeth I.5) - probably the most famous 'case' of emasculation in the history of literature.

Structurally, The Testaments is similar to The Handmaid's Tale, in that both are framed by 'Historical Notes' - advanced during the proceedings of The Thirteenth and Twelfth Symposium on Gileadean Studies held in 2197 and 2195 as part of a series of International Historical Association Conventions (2019, 407-15 and 2010, 311-24). The role of the 'Notes' seems to be that of adding architectural depth to the embedded narratives, while relativizing historical time by looking back at our future from someone else's present. Furthermore, they may be considered instrumental for Atwood in her obvious pursuit of highlighting the fuzzy frontier between reality and fiction, and of questioning their related myths, which posit that the former equals truth and is therefore masculine, while the latter is un-truth, ergo easily associated with femininity. "If I was to create an imaginary garden, I wanted the toads in it to be real,' she wrote in a recent introduction to The Handmaid's Tale. And this is 'absolutely' the case for The Testaments: shadows of Weinstein and Epstein, ISIS and the Trump administration can all be found in its murky waters" (The Guardian, 20 September 2019).

Inside their frames, the novels hide, only gradually revealing to the inquisitive reader, several tales or pieces of a puzzle to be solved. The Handmaid's Tale gives Offred a narrator's voice, and includes the protagonist's version of her life and that of her fellow handmaids in dystopian Gilead (arranged into fifteen alternating stories), while The Testaments brings together three narrative voices (Lydia's, Agnes Jemima's and Daisy's/Nicole's), each connected to The Handmaid's Tale and to Offred (although focusing on events happening fifteen years later), all convergent towards a rather unexpected happy-ending.

In what follows, we will refer to them in turn, starting with "the definitive account of [Aunt Lydia's] life and times, suitably footnoted" (Atwood 2019, 403). The evolution in The Handmaid's Tale of this emasculated character and her attempts at definitively inscribing history with her authoritative, ergo biased, standpoint make it complicated to even try to associate Aunt Lydia with feminism. Nevertheless, the meaning resulting from Derrida's linguistic contrivance, namely deferral, may help to 'excuse' her ruthless behaviour: she suspends her femininity and defers feminine solidarity until she feels that she can truly upset the status quo and overthrow male domination through feminine power.

This power lies in language, in subversive games of double meanings - as is the case with the Latin ending formula of graces - Per Ardua cum Estrus, "Through childbirth labour with the 
female reproductive cycle" (Atwood 2019, 289) - apparently having to do with the desperate need of Gilead to increase the birth rate. It can also be read as (going through) hard times and adversity with frenzy - a frenzy specific to women, corresponding to the Victorian hysterics or to the mythical Bacchantes - which acquires an extremely violent form in the Particicutions: "men being literally ripped apart by handmaids" or "torn apart by a mob of frenzied women" $(2019,286 ; 322)$. More powerful than this gruesome act is, nonetheless, the power of reading and writing, which has been taken away from all Gileadean women except for the Aunts. "Women's minds were too weak for reading. We would crumble, we would fall apart under the contradictions, we would not be able to hold firm" $(2019,303)$. As for writing, the écriture féminine that will eventually overthrow men's power and help women $f y$ away from the imposing patriarchal paradigm of the regime is, accordingly, Lydia's. If "woman must write her self: must write about women and bring women to writing, from which they have been driven away as violently as from their bodies" in order to evade "the discourse that regulates the phallocentric system," as Cixous states in "The Laugh of the Medusa" (1976), then Atwood's option for the stereotypically feminine diary form may be interpreted as a transposition of this theory of destabilizing phallocentric hierarchies into practice. Aunt Lydia writes herself in diaries addressed, metafictionally, to an unknown reader; she writes her-story, which becomes the history of the totalitarian Gilead itself, and brings women to writing by creating an order of feminine power in its own right - one that would regain language and power, or the power of language, whichever comes first.

As mentioned above, in writing a 'political grammar of feminist theory,' Clare Hemmings (2011) has identified the many aspects of this theory with "stories of loss, progress, and return." If one were to continue with the analogy between the waves of feminism and the developments in The Handmaid's Tale, one could associate Offred's tale with a story of loss (of her family, child, rights, dignity and freedom) which follows all the gains of the second wave. In The Testaments, however, life goes on; only it is not Offred's, as she is only referred to in the metafictional addendum that replicates the one in the original novel. The reader infers, relatively quickly, from the pages of the Transcripts of Witness Testimony $369 A$ and $369 B$ (i.e., the first-person narratives of the progress of two young women) that the two are her lost daughters. Agnes Jemima, who will, later in the novel, join Aunt Lydia's subversive army of women as Aunt Victoria, learns that she has been adopted by the Commander's family that raised her. She has distant and blurry memories of running through the woods, which easily match the flashbacks of Offred and Luke's failed attempt to escape Gilead (in The Handmaid's Tale).

It is mainly through Agnes Jemima's testimony that the reader is informed about the progress/ regress of Gilead in the fifteen years that have passed since the inconclusive ending of Offred's narrative. Atwood constructs a Puritan-inspired theocracy that is more settled and less violent, but not less frightening than the one in her original novel. "The official line was that there were no corrupt Angels, and certainly no fleeing Handmaids; for why would one renounce God's kingdom to plunge into the flaming pit?" (2019, 278). In fact, women are stripped of all rights but that of being minimally educated (religion and crafts at first, and 'premarital preparatory' around the age of thirteen, when they reach puberty). Of course, they become wives of husbands whom they do not get to choose. They also 'happen' to conveniently die when the Commanders want a new, younger wife. Men in power abuse them sexually - it is their word against the women's, with the latter being too scared to speak up, since those 
who did were punished instead of their molesters. Joining the Aunts' ranks also provides the possibility of becoming a Pearl Girl and going to Canada to carry out religious/political proselytism for Gilead. Consistent with her frequent borrowings from reality, Atwood portrays these missionaries so as to resemble both the Puritan women of early seventeenth-century America and the pairs of Jehovah's Witnesses who can be seen handing out leaflets all over the world: "two of them, in their silvery grey dresses with long skirts, their white collars, their white hats" (2019, 261). Also consistent with her penchant for intertextuality, she gives these girls the name of Hester Prynne's daughter (Nathaniel Hawthorne, The Scarlet Letter). This route seems (and eventually turns out to be) an escape from a form of womanhood returned to the ages before the first wave. Given the gift of reading, Agnes Jemima / Aunt Victoria learns the inner workings of the women's resistance in Gilead. She is eventually reunited with her lost sister (the third narrator) and set on a course of destroying Gilead from within, alongside Mayday (the underground organization supporting potential fugitives), whose agent Aunt Lydia has been for a long time.

The third narrative is set in Canada, and its protagonist and narrator is Daisy, a fifteen-yearold girl (a strategy which, as an aside, gives Atwood the opportunity to successfully try her hand at the style and language of young adult fiction). Daisy too is adopted, and feels that she is overprotected. Her only apparent connection to Gilead seems to be her annoyance at the Baby Nicole propaganda on both sides. Nicole is the name of the baby that Offred gives birth to in the TV series, which Atwood retains in her sequel to make the lost child a symbol for both parties: Gilead has made her a national martyr, instituting prayers for her return to the bosom of her motherland (but not mother), repeatedly requesting her extradition from the Canadian authorities; at the same time, she is a symbol of freedom, a signpost of Mayday's success in escaping the horrors of the theocracy so vilely established south of Canada. The teenager expresses her boredom with the topic in a school essay which claims that the baby (who is, of course, no longer a baby by now) should be simply returned to Gilead, unaware that she is herself the baby in question. She will learn this after her adoptive parents, members of the resistance, are killed following her exposure in an anti-Gilead rally. Daisy/Nicole (Jade upon entrance into Gilead) is given the mission to overthrow the regime, which she does, in a fast-paced, story that leads her to Ardua Hall, Aunt Lydia and her step-sister, Agnes Jemima/Aunt Victoria, and then back to Canada. Reunited, the two young women succeed in becoming the 'fourth-wavers' who deliver Gilead (and the USA) from male abuse, thus completing the circle of the narratives of loss, progress and return.

Unlike the "Historical Notes to the Handmaid's Tale" and their 'authenticating' efforts which subvert all that has been read in the novel, the similar metafictional addendum at the end of The Testaments comes to substantiate, in Pieixoto's keynote during the Thirteenth Symposium on Gileadean Studies, the authenticity of the three women's writings. The arrogant, misogynistic Professor - who, in The Handmaid's Tale, cannot refrain from adding a Chaucerian tone to a woman's narrative efforts, mentioning "the archaic vulgar signification of the word tail; [or...] the bone, as it were, of contention, in that phase of Gileadean society" (Atwood 2010, 313) - acknowledges, in The Testaments, that "women are usurping leadership positions to such a terrifying extent" (Atwood 2019, 408), resuming the plot development as a result. Moreover, after having criticized the femininity (or 'unreliability') of Offred's recorded diaries in the 1985 novel, he ends by merging "the three batches of materials... in an order 
that made approximate narrative sense" $(2019,414)$ and editing their content by adding sections, references and footnotes. In other words, he brings his story to the existing materials and makes metafictional corrections, hence conferring on them the historical authenticity required to deem them documents of the fall of the Gileadean system.

"You can take the historian out of the storyteller, but you can't take the storyteller out of the historian!" $(2019,414)$ concludes Atwood, manipulating Pieixoto, as the genuine storyteller of alternative history that she has been throughout her career. In so doing, at the surface level she wraps up Offred's tale with a historical account of the abusive male(volent) empire. The undercurrents of the feminist surge, however, converge and threaten the margins of the metafictional frame.

\section{References}

Atwood, Margaret. (1985) 2010. The Handmaid's Tale. London: Vintage.

-. 2019a. The Testaments. London: Vintage.

—. 2019b. "Margaret Atwood: For a long time we were moving away from Gilead." Interview by Lisa Allardice. The Guardian, September 20, 2019. https://www.theguardian.com/books/2019/sep/20 /margaret-atwood-moving-away-from-gilead-testaments.

Barthes, Roland. 1967. "The Death of the Author." Translated by Richard Howard. Aspen: The Magazine in a Box 5+6. http://www.ubu.com/aspen/aspen5and6/threeEssays.html\#barthes.

Baumgardner, Jennifer. 2011. F'EM! Goo Goo, Gaga, and Some Thoughts on Balls. Berkeley: Seal Press. Chamberlain, Prudence. 2017. The Feminist Fourth Wave. Affective Temporality. London: Palgrave Macmillan. Cixous, Hélène. 1976. "The Laugh of the Medusa." Translated by Keith and Paula Cohen. Signs 1 (4): 875-93. https://www.jstor.org/stable/3173239.

—. 1986. "Sorties: Out and Out: Attacks/Ways Out/Forays Introduction, Katarzyna Marciniak." In The Newly Born Woman, by Hélène Cixous, Catherine Clement and Betsy Wing, 63-130. Minneapolis: University of Minnesota Press.

Enright, Anne. 2019. "The Testaments by Margaret Atwood review: A dazzling follow-up to The Handmaid's Tale." The Guardian, September 10, 2019. https://www.theguardian.com/books/2019/sep/10/the -testaments-by-margaret-atwood-review.

Faludi, Susan. 2006. Backlash. The Undeclared War against American Women. New York: Three Rivers Press. Friedan, Betty. 2001. The Feminine Mystique. New York: W.W. Norton \& Company.

Genz, Stephanie, and Benjamin Brabon. 2009. Postfeminism: Cultural Texts and Theories. Edinburgh: Edinburgh University Press.

Halberstam, J. J. 2012. Gaga Feminism: Sex, Gender and the End of Normal. Massachusetts: Beacon Press. Hemmings, Clare. 2011. Why Stories Matter: The Political Grammar of Feminist Theory. Durham: Duke University Press.

Howells, Coral Ann. 2003. "Margaret Atwood's Dystopian Visions: The Handmaid's Tale and Oryx and Crake." In The Cambridge Companion to Margaret Atwood, edited by Coral Ann Howells, 161-75. Cambridge: Cambridge University Press.

Joyce, James. 2010. Ulysses. London: Wordsworth Classics.

Praisler, Michaela, and Oana Gheorghiu. 2019. "The Art and Politics of Rewriting. Margaret Atwood's 'Historical Notes on the Handmaid's Tale."' Cultural Intertexts VI (9): 171-81.

Rivers, Nicola. 2017. Postfeminism(s) and the Arrival of the Fourth Wave. Turning Tides. London: Palgrave Macmillan.

Shakespeare, William. 2007. Macbeth. In Shakespeare's Tragedies, edited by David Bevington, 1255-92. New York: Pearson Longman.

Vick, Karl. 2017. "Perhaps the Largest Protest in US History Was Brought to You by Trump.” Time, January 26, 2017. https://time.com/4649891/protest-donald-trump/. 